Atmos. Chem. Phys., 10, 1183-1192, 2010

www.atmos-chem-phys.net/10/1183/2010/

(C) Author(s) 2010. This work is distributed under

the Creative Commons Attribution 3.0 License.

\title{
Mercury emission and speciation of coal-fired power plants in China
}

\author{
S. X. Wang ${ }^{1}$, L. Zhang ${ }^{1}$, G. H. Li ${ }^{1}$, Y. Wu ${ }^{1}$, J. M. Hao ${ }^{1}$, N. Pirrone ${ }^{2}$, F. Sprovieri ${ }^{2}$, and M. P. Ancora ${ }^{2}$ \\ ${ }^{1}$ Department of Environmental Science and Engineering, and State Key Joint Laboratory of Environment Simulation and \\ Pollution Control, Tsinghua University, Beijing 100084, China \\ ${ }^{2}$ CNR - Institute of Atmospheric Pollution Research, Via Salaria Km 29.300-CP10, 00015 Monterotondo St., Rome, Italy
}

Received: 29 September 2009 - Published in Atmos. Chem. Phys. Discuss.: 12 November 2009

Revised: 14 January 2010 - Accepted: 14 January 2010 - Published: 3 February 2010

\begin{abstract}
Comprehensive field measurements are needed to understand the mercury emissions from Chinese power plants and to improve the accuracy of emission inventories. Characterization of mercury emissions and their behavior were measured in six typical coal-fired power plants in China. During the tests, the flue gas was sampled simultaneously at inlet and outlet of Selective Catalytic Reduction (SCR), electrostatic precipitators (ESP), and flue gas desulfurization (FGD) using the Ontario Hydro Method (OHM). The pulverized coal, bottom ash, fly ash and gypsum were also sampled in the field. Mercury concentrations in coal burned in the measured power plants ranged from 17 to $385 \mu \mathrm{g} / \mathrm{kg}$. The mercury mass balances for the six power plants varied from 87 to $116 \%$ of the input coal mercury for the whole system. The total mercury concentrations in the flue gas from boilers were at the range of $1.92-27.15 \mu \mathrm{g} / \mathrm{m}^{3}$, which were significantly related to the mercury contents in burned coal. The mercury speciation in flue gas right after the boiler is influenced by the contents of halogen, mercury, and ash in the burned coal. The average mercury removal efficiencies of ESP, ESP plus wet FGD, and ESP plus dry FGD-FF systems were $24 \%, 73 \%$ and $66 \%$, respectively, which were similar to the average removal efficiencies of pollution control device systems in other countries such as US, Japan and South Korea. The SCR system oxidized 16\% elemental mercury and reduced about $32 \%$ of total mercury. Elemental mercury, accounting for 66-94\% of total mercury, was the dominant species emitted to the atmosphere. The mercury emission factor was also calculated for each power plant.
\end{abstract}

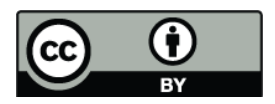

Correspondence to: S. X. Wang (wangshuxiao@tsinghua.org.cn)

\section{Introduction}

Mercury $(\mathrm{Hg})$ is one of the most important environmental contaminants that has aroused a global concern due to its toxicity, long range transport, persistence and bioaccumulation in the environment. Coal combustion is believed to be the main source of mercury emissions to the atmosphere, accounting for $60 \%$, or even more, of the total mercury emissions (Pacyna et al., 2006). Streets et al. (2009) suggested that the change of global anthropogenic $\mathrm{Hg}$ emissions may range anywhere from $-4 \%$ to $+96 \%$ by 2050 , depending on future implementation of best available technology (BAT) in coal-fired utilities and energy demand.

Mercury is present in coal in trace amounts (0.01$0.5 \mathrm{mg} / \mathrm{kg}$ ). At the high temperatures in combustion zone of boilers, combustion releases the $\mathrm{Hg}$ in coal into the exhaust gas as elemental mercury $\left(\mathrm{Hg}^{0}\right)$. This vapor may then be oxidized by $\mathrm{HCl}, \mathrm{SO}_{2}$, and fly ash in flue gas due to thermo-chemical processes (Meij et al., 2002; Niksa et al., 2004; Lee et al., 2006; Park et al., 2008). Oxidized mercury $\left(\mathrm{Hg}^{2+}\right)$ is soluble and has a tendency to associate with the particles in flue gas to form particulate-bound mercury $\left(\mathrm{Hg}_{p}\right)$. Therefore, emissions of $\mathrm{Hg}^{2+}$, may be efficiently controlled by typical air pollution control devices (APCD), such as electrostatic precipitators (ESP), fabric filter (FF), and flue gas desulfurization (FGD) systems (US EPA, 1997, 2000b, 2002a). However, because the relative proportions of $\mathrm{Hg}^{2+}, \mathrm{Hg}_{p}$ and $\mathrm{Hg}^{0}$ can vary widely, the corresponding reductions in total mercury achieved by APCD vary (Pavlish et al., 2003; Srivastava et al., 2006; Lee et al., 2008; Cao et al., 2008a). For example, the removal efficiency of $\mathrm{Hg}$ from the flue gas by a combination of cold side ESP and wet FGD range from 24 to $70 \%$. Emission speciation is an important source of uncertainty when assessing the atmospheric fate

Published by Copernicus Publications on behalf of the European Geosciences Union. 
of mercury because $\mathrm{Hg}^{2+}, \mathrm{Hg}_{p}$ and $\mathrm{Hg}^{0}$ have very different physico-chemical characteristics and, consequently, different atmospheric lifetimes.

As the largest coal producer and consumer in the world, China releases amounts of $\mathrm{Hg}$ that have been increasing rapidly in recent years and are getting more and more attention (Wu et al., 2006; Pirrone et al., 2009). Wu et al. (2006) estimated mercury emissions from coal-fired power plants in China have been growing at an annual growth rate of 5.9\% during 1995-2003, much higher than the average growth rate of all coal consumption sectors. By 2007, the coal consumption by power generation in China increased to 1.49 billion tons, indicating an even higher annual growth rate during 2004-2007.

However, mercury emissions for China have large uncertainties because comprehensive field tests to characterize $\mathrm{Hg}$ emissions from coal-fired power stations are only available for the developed countries such as The Netherlands (Meij and Winkel, 2006), United States (US EPA, 2002b) and Japan (Yokoyama et al., 2000; Ito et al., 2006). Due to the paucity of information on $\mathrm{Hg}$ emission rates, speciation profiles from Chinese utility boilers and the capture of $\mathrm{Hg}$ in Chinese air pollution control devices, the uncertainty of total $\mathrm{Hg}$ emissions was estimated to be approximately $-40 \% /+70 \%$ for coal-fired power plants in China (Streets et al., 2005; Wu et al., 2009). There are even higher uncertainties for the speciation profiles. Therefore there has been increasing needs to characterize the $\mathrm{Hg}$ emissions from coal-fired power plants in China (Niksa and Fujiwara, 2009; Clack, 2009).

Up to now, mercury emission tests have been conducted only for a few power plants in China (Chen et al., 2007; Zhang et al., 2008; Tang et al., 2007). Chen et al. (2007) and Zhang et al. (2008) reported $\mathrm{Hg}$ speciation data based on flue gas monitoring with the Ontario Hydro protocol from 6 plants at the inlets and outlets to the particle collection devices. They found that the average mercury removal efficiency of the ESP systems was $11 \%$, and that of the FF systems was $52 \%$, much lower than the average removal efficiencies of pollution control devices in US plants. The tests also indicated that share of $\mathrm{Hg}^{0}$ vs. total $\mathrm{Hg}$ in Chinese boilers is much higher than that found in US boilers. For example, the share of $\mathrm{Hg}^{0}$ is $26 \%$ on average for the outlet of ESPs tested in the US, while such ratio increases to $56 \%$ on average for Chinese boilers, which may be mainly because the compositions of Chinese coals differ from those of US coals. At the end of 2008, about $48 \%$ of Chinese coal-fired power plants were equipped with FGD. Considering that FGDs are going to be installed in all new units (according to the 11th five-year plan), the application rate of FGDs will reach up to $60 \%$ in 2010 and will keep increasing during 2010-2020 (Zhao et al., 2008). However, the test data for Hg emissions from coal-fired power plants with ESPs plus FGD are scarce in China. Therefore, more field tests are needed on more Chinese power plants to understand the full details of mer- cury partitioning and emissions from Chinese power plants, especially those with ESPs plus FGD.

In this paper, we present a comprehensive analysis of onsite measurements for mercury emission and behavior in six Chinese coal-fired power plants. The Ontario Hydro Method was used to sample the mercury in flue gases, at the inlet of the APCDs and at the stack, in order to understand the change in chemical forms of mercury. The fate of $\mathrm{Hg}$ in coal-fired power plants, including its removal by APCDs was quantified by collecting and analyzing gaseous samples as well as solid samples such as coal, fly ash, bottom ash, gypsum (byproduct from FGD), and effluents. The assessment of mercury emission and total mercury mass balance was estimated from the gathered sample data.

\section{Experimental methods}

\subsection{Power plants tested}

Onsite tests were carried out in six typical coal-fired power plants across China, covering the most common unit types in terms of boiler variety, coal quality, and emission control device. As shown in Table 1, all the tested units are pulverized coal boilers ranging from 100 to $600 \mathrm{MW}$. Among these units, three of them burn bituminous coal, two burn lignite coal and one burns anthracite coal. All tested units have ESP or FF systems for removing particles in flue gases. Five of six tested units install wet FGD while plant 5 uses CFB-FGD, a type of dry FGD, to control $\mathrm{SO}_{2}$ emissions. Plant 6 installs Selective Catalytic Reduction system (SCR) to control $\mathrm{NO}_{\mathrm{x}}$ emissions. During the test period, all of the power units were operating under normal conditions.

\subsection{Sampling and analysis methods}

The APCD configuration and all the sampling locations in power plants are shown in Fig. 1. The Ontario Hydro Method (ASTM, 2002) was performing onsite tests for total mercury and speciation profile at inlet/outlet of SCR (if applicable), ESP, and FGD. The samples were withdrawn from the flue gas stream isokinetically through a probe/filter system maintaining the flue gas at $120^{\circ} \mathrm{C}$, which is followed by a series of impingers in an ice bath. The particulate-bound mercury is collected on the quartz fiber filter. The $\mathrm{Hg}^{2+}$ is collected in the first three impingers with $1.0 \mathrm{~mol} / \mathrm{L}$ potassium chloride $(\mathrm{KCl})$ solution and $\mathrm{Hg}^{0}$ is collected in subsequent impingers, of which one impinger containing a $5 \%$ nitric acid $\left(\mathrm{HNO}_{3}\right)$ and $10 \%$ peroxide $\left(\mathrm{H}_{2} \mathrm{O}_{2}\right)$ solution and three impingers with a solution of $10 \%$ sulfuric acid $\left(\mathrm{H}_{2} \mathrm{SO}_{4}\right)$ and $4 \%$ potassium permanganate $\left(\mathrm{KMnO}_{4}\right)$, as shown in Fig. 2.

Liquid and solid samples were collected in the field and analyzed in accordance with US EPA 7470A for liquid samples and 7473 for solid samples. The impinger solutions are recovered and analyzed with Cold Vapor Atomic Absorption Spectrophotometry (CVAAS) type mercury analyzer with a 
Table 1. Information of the onsite tested utility boilers.

\begin{tabular}{|c|c|c|c|c|c|c|}
\hline Power plant & Installed capacity (Mw) & Location & Boiler type & Air pollution control devices (APCDs) & Coal type & Coal consumption $(\mathrm{kt} / \mathrm{yr})$ \\
\hline Plant 1 & 200 & Guizhou & $\mathrm{PC}$ boiler & ESP+WFGD & Bituminous & 894 \\
\hline Plant 2 & 600 & Guizhou & PC boiler & ESP+WFGD & Bituminous & 1672 \\
\hline Plant 3 & 300 & Guizhou & PC boiler & ESP+WFGD & Anthracite & 836 \\
\hline Plant 4 & 600 & Guangdong & $\mathrm{PC}$ boiler & ESP+WFGD & Lignite & 1280 \\
\hline Plant 5 & 100 & Shanxi & PC boiler & $\mathrm{ESP}+\mathrm{CFB}-\mathrm{FGD}+\mathrm{FF}$ & Bituminous & 363 \\
\hline Plant 6 & 165 & Beijing & PC boiler & SCR+ESP+WFGD & Lignite & 452 \\
\hline
\end{tabular}

Notes: PC boiler - pulverized-coal boiler

ESP - electrostatic precipitator

FF - fabric filter

FGD - flue gas desulfurization

WFGD - wet FGD

CFB-FGD - circulating fluidized bed FGD

$\mathrm{SCR}$ - selective catalytic reduction

Table 2. Proximate and ultimate analysis of tested coals.

\begin{tabular}{lllllllllllllll}
\hline Coal sample & \multicolumn{1}{c}{ Proximate analysis } \\
& $\begin{array}{llllllllllllll}\mathrm{M}_{a d} \\
\end{array}$ & $\begin{array}{l}\mathrm{A}_{d} \\
\%\end{array}$ & $\begin{array}{l}\mathrm{V}_{\text {daf }} \\
\mathrm{FC}_{d}\end{array}$ & $\begin{array}{l}\mathrm{Q} \\
\mathrm{MJ}\end{array}$ & $\begin{array}{l}\mathrm{C}_{d} \\
\%\end{array}$ & $\begin{array}{l}\mathrm{H}_{d} \\
\%\end{array}$ & $\begin{array}{l}\mathrm{N}_{d} \\
\%\end{array}$ & $\begin{array}{l}\mathrm{O}_{d} \\
\%\end{array}$ & $\begin{array}{l}\mathrm{S}_{d} \\
\%\end{array}$ & $\begin{array}{l}\mathrm{Cl} \\
\mathrm{mg} / \mathrm{kg}\end{array}$ & $\begin{array}{l}\mathrm{F} \\
\mathrm{mg} / \mathrm{kg}\end{array}$ & $\begin{array}{l}\mathrm{Br} \\
\mathrm{mg} / \mathrm{kg}\end{array}$ & $\begin{array}{l}\mathrm{Hg} \\
\mu \mathrm{g} / \mathrm{kg}\end{array}$ \\
\hline Plant 1 & 1.70 & 32.49 & 15.30 & 57.18 & 21.17 & 59.35 & 2.41 & 0.92 & 0.80 & 4.03 & $63 \pm 46(4)$ & $215 \pm 25$ & $55 \pm 19$ & $233 \pm 12(6)$ \\
Plant 2 & 1.27 & 34.37 & 25.06 & 49.18 & 19.60 & 57.27 & 3.06 & 0.95 & 3.21 & 1.14 & $190 \pm 115(4)$ & $150 \pm 55$ & $34 \pm 17$ & $142 \pm 38(3)$ \\
Plant 3 & 1.74 & 31.06 & 12.31 & 60.45 & 20.51 & 59.82 & 2.22 & 0.92 & 2.02 & 3.96 & $117 \pm 32(3)$ & $235 \pm 26$ & $55 \pm 22$ & $174 \pm 19(6)$ \\
Plant 4 & 7.60 & 21.34 & 35.99 & 50.35 & 21.73 & 62.18 & 3.46 & 0.76 & 11.70 & 0.56 & $136 \pm 15(5)$ & $\mathrm{N} . \mathrm{A}$. & $\mathrm{N} . \mathrm{A}$. & $35 \pm 10(5)$ \\
Plant 5 & 1.25 & 36.32 & 24.11 & 48.33 & 20.51 & 52.39 & 2.88 & 0.79 & 5.22 & 2.40 & $318 \pm 68(4)$ & $149 \pm 43$ & $63 \pm 6$ & $385 \pm 113(5)$ \\
Plant 6 & 6.11 & 7.42 & 34.70 & 60.46 & 22.82 & 75.52 & 4.13 & 0.84 & 11.65 & 0.44 & $160 \pm 83(4)$ & $114 \pm 32$ & $42 \pm 7$ & $17 \pm 5(7)$ \\
\hline
\end{tabular}

Note: the numbers in brackets are number of samples analyzed; the numbers of samples for analysis of $\mathrm{F}$ and $\mathrm{Br}$ are same as that for analysis of $\mathrm{Cl}$ content.

detection limit of $0.005 \mu \mathrm{g} / \mathrm{m}^{3}$. The samples of coal, fly ash, bottom ash and gypsum were analyzed with Direct Mercury Analyzer (Milestone DMA-80, Italy) with a detection limit of $0.05 \mu \mathrm{g} / \mathrm{g}$.

\subsection{Quality assurance and quality control (QA/QC)}

All sampling tests and analysis were carried out in triplicate or more to obtain parallel results and reduce uncertainties. The parallel tests were found to be reproducible. Differences of tests in each sampling site are within a range of $\pm 20 \%$, which is acceptable for onsite tests. Most of the differences came from the fluctuation of flue gas because of the time difference of sampling. The error in the analytical procedure is less than $5 \%$. The data obtained from tests at the same conditions were averaged to get the final results.

Each of the seven impingers in the sampling train of Ontario Hydro Method was recovered and analyzed separately. Thereby the success of the sample collection can be evaluated. For example, if the first $\mathrm{KCl}$ impinger collected over $85 \%$ of the $\mathrm{Hg}^{2+}$ and the last one collected less than $5 \%$, we could have a reasonable degree of confidence that the $\mathrm{Hg}^{2+}$ had been successfully collected. Otherwise we would hypothesize that a considerable breakthrough of mer- cury species had occurred and the sample collection was not successful.

The removal efficiencies of APCDs can be calculated either by the mercury concentration in flue gas at inlet/outlet of APCDs or by the mass balance. The removal efficiency based on the mercury concentration in flue gas at inlet/outlet of APCDs and that based on the mass balancing were compared and their differences were less than $20 \%$.

\section{Results and discussion}

\subsection{Properties of feed-coal}

The six selected plants are located in different parts of China, and thus the coal collected from each plant has different qualities. Differences in coals quality may lead to a different behavior of mercury species in the flue gas. The results of proximate and ultimate analysis of feed-coals were presented in Table 2. The contents of mercury, chlorine $(\mathrm{Cl})$ and ash in coal have significant impacts on $\mathrm{Hg}$ speciation. The mercury content in these coals varies from 17 to $385 \mu \mathrm{g} / \mathrm{kg}$, which agrees with mercury contents of $10-570 \mu \mathrm{g} / \mathrm{kg}$ in Chinese coals found by other researchers (USGS, 2004; Zheng 


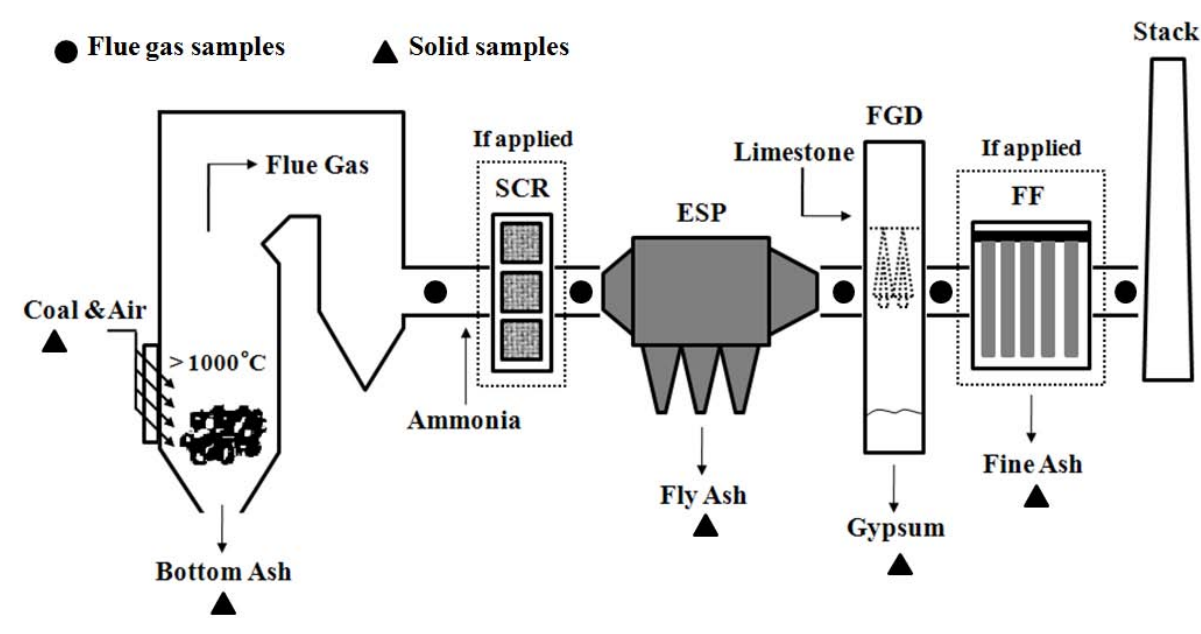

Fig. 1. Sampling locations in tested power plants.

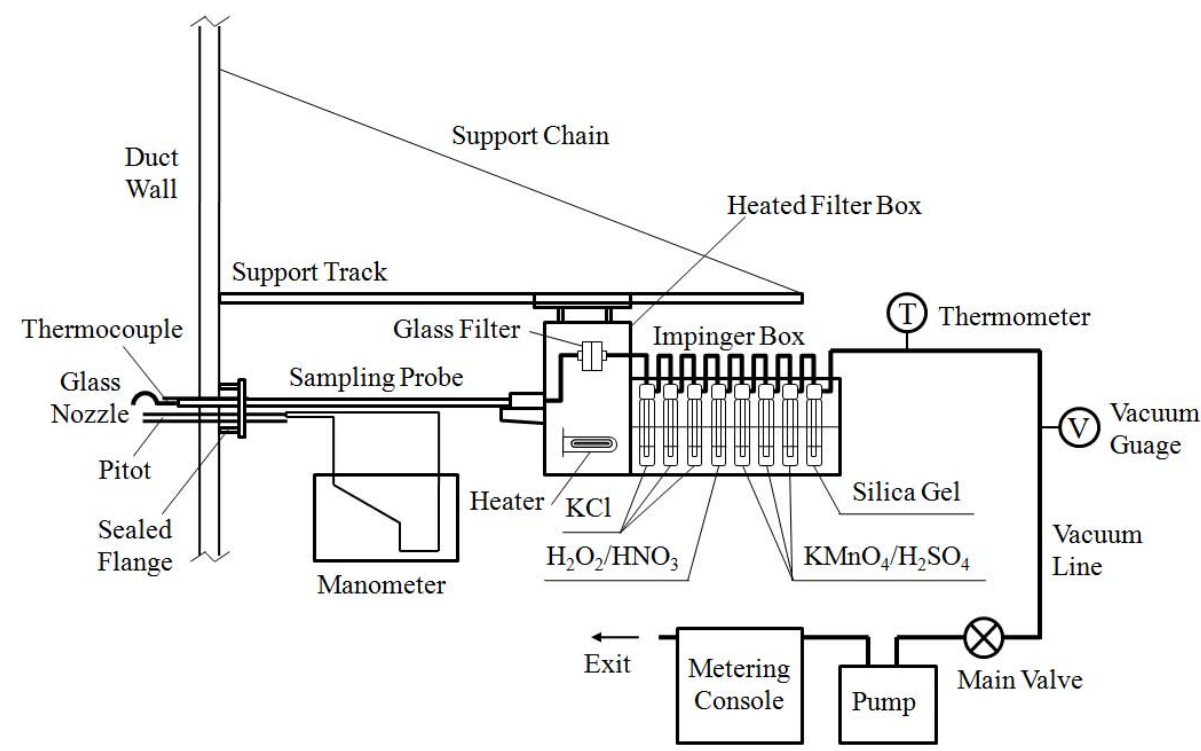

Fig. 2. Ontario Hydro Method for measuring mercury speciation in flue gas.

et al., 2007a, b). The chlorine content in feed-coal varies from $63-318 \mathrm{mg} / \mathrm{kg}$, which is much lower than the average value of US coals, $628 \mathrm{mg} / \mathrm{kg}$ (Ren et al., 2006). The ash content of tested coals varies from 7.42 to $36.32 \%$ and sulfur content ranges from 0.44 to $4.03 \%$. The ash and sulfur content of coals used in plant $1-5$ is much higher than that in US coals. To identify the impacts of bromine $(\mathrm{Br})$ and fluorine $(\mathrm{F})$ on $\mathrm{Hg}$ emissions, we also analyzed the content of $\mathrm{Br}$ and $\mathrm{F}$ in tested coals. The results indicate that the fluorine in coal ranges from 114 to $235 \mathrm{mg} / \mathrm{kg}$ and bromine from 34 to $63 \mathrm{mg} / \mathrm{kg}$.

\subsection{Mercury concentration and speciation in flue gas}

Table 3 gives the concentrations of total $\mathrm{Hg}, \mathrm{Hg}^{0}, \mathrm{Hg}^{2+}$ and $\mathrm{Hg}_{p}$ across APCDs in 6 power plants. All the data are normalized to dry flue gas in standard conditions.

\subsubsection{Mercury release from coal combustion}

The total mercury concentration in flue gas at inlet of ESP (at inlet of SCR for plant 6) varies over a large range, from 1.92 to $27.15 \mu \mathrm{g} / \mathrm{m}^{3}$. There is significant correlation between the mercury content of coal and the total mercury concentration in flue gas released from the tested boilers (as shown in Fig. 3), with a correlation coefficient of 0.98 for bituminous and lignite coal-fired boilers. The anthracite coalburning unit emitted higher concentration of total mercury 
Table 3. Concentrations of different mercury species in flue gas at each sampling location.

\begin{tabular}{|c|c|c|c|c|c|c|c|}
\hline & & Plant 1 & Plant 2 & Plant 3 & Plant 4 & Plant 5 & Plant 6 \\
\hline \multirow{4}{*}{$\begin{array}{l}\text { Before SCR } \\
\left(\mu \mathrm{g} / \mathrm{m}^{3}\right)\end{array}$} & Total Hg & & & & & & $1.92 \pm 0.05$ \\
\hline & $\mathrm{Hg}^{2+}$ & & & & & & $0.15 \pm 0.04$ \\
\hline & $\mathrm{Hg}^{0}$ & & & & & & $1.55 \pm 0.12$ \\
\hline & $\mathrm{Hg}_{p}$ & & & & & & $0.22 \pm 0.02$ \\
\hline \multirow{4}{*}{$\begin{array}{l}\text { Before ESP } \\
\left(\mu \mathrm{g} / \mathrm{m}^{3}\right)\end{array}$} & Total $\mathrm{Hg}$ & $20.77 \pm 2.17$ & $15.06 \pm 1.99$ & $27.15 \pm 0.46$ & $3.13 \pm 0.13$ & $26.93 \pm 2.33$ & $1.89 \pm 0.13$ \\
\hline & $\mathrm{Hg}^{2+}$ & $11.42 \pm 0.74$ & $4.64 \pm 0.83$ & $22.22 \pm 0.35$ & $0.42 \pm 0.11$ & $23.73 \pm 1.83$ & $0.40 \pm 0.10$ \\
\hline & $\mathrm{Hg}^{0}$ & $6.00 \pm 0.66$ & $7.05 \pm 0.32$ & $2.11 \pm 0.32$ & $2.48 \pm 0.26$ & $2.78 \pm 0.40$ & $1.02 \pm 0.07$ \\
\hline & $\mathrm{Hg}_{p}$ & $3.36 \pm 0.17$ & $3.37 \pm 0.53$ & $2.82 \pm 0.36$ & $0.23 \pm 0.04$ & $0.42 \pm 0.10$ & $0.47 \pm 0.02$ \\
\hline \multirow{4}{*}{$\begin{array}{l}\text { After ESP } \\
\left(\mu \mathrm{g} / \mathrm{m}^{3}\right)\end{array}$} & Total $\mathrm{Hg}$ & $13.20 \pm 1.89$ & $8.07 \pm 1.15$ & $24.35 \pm 0.64$ & $2.94 \pm 0.11$ & $21.96 \pm 4.13$ & $1.44 \pm 0.04$ \\
\hline & $\mathrm{Hg}^{2+}$ & $8.92 \pm 1.24$ & $3.99 \pm 0.39$ & $17.90 \pm 0.58$ & $0.42 \pm 0.06$ & $18.36 \pm 3.64$ & $0.44 \pm 0.03$ \\
\hline & $\mathrm{Hg}^{0}$ & $4.27 \pm 0.74$ & $4.08 \pm 0.63$ & $6.44 \pm 0.55$ & $2.50 \pm 0.14$ & $3.58 \pm 0.57$ & $1.00 \pm 0.03$ \\
\hline & $\mathrm{Hg}_{p}$ & $0.01 \pm 0.00$ & $0.00 \pm 0.00$ & $0.00 \pm 0.00$ & $0.02 \pm 0.00$ & $0.02 \pm 0.00$ & $0.00 \pm 0.00$ \\
\hline \multirow{4}{*}{$\begin{array}{l}\text { After FGD } \\
\left(\mu \mathrm{g} / \mathrm{m}^{3}\right)\end{array}$} & Total $\mathrm{Hg}$ & $6.69 \pm 1.24$ & $4.53 \pm 0.68$ & $5.06 \pm 0.43$ & $2.27 \pm 0.19$ & & $1.22 \pm 0.12$ \\
\hline & $\mathrm{Hg}^{2+}$ & $1.66 \pm 0.64$ & $0.84 \pm 0.20$ & $0.45 \pm 0.09$ & $0.14 \pm 0.03$ & & $0.13 \pm 0.02$ \\
\hline & $\mathrm{Hg}^{0}$ & $5.03 \pm 1.05$ & $3.70 \pm 0.40$ & $4.61 \pm 0.46$ & $2.13 \pm 0.20$ & & $1.08 \pm 0.11$ \\
\hline & $\mathrm{Hg}_{p}$ & $0.00 \pm 0.00$ & $0.00 \pm 0.00$ & $0.00 \pm 0.00$ & $0.00 \pm 0.00$ & & $0.00 \pm 0.00$ \\
\hline \multirow{4}{*}{$\begin{array}{l}\text { After FF } \\
\left(\mu \mathrm{g} / \mathrm{m}^{3}\right)\end{array}$} & Total $\mathrm{Hg}$ & & & & & $9.16 \pm 1.69$ & \\
\hline & $\mathrm{Hg}^{2+}$ & & & & & $3.04 \pm 0.64$ & \\
\hline & $\mathrm{Hg}^{0}$ & & & & & $6.11 \pm 1.09$ & \\
\hline & $\mathrm{Hg}_{p}$ & & & & & $0.01 \pm 0.00$ & \\
\hline
\end{tabular}

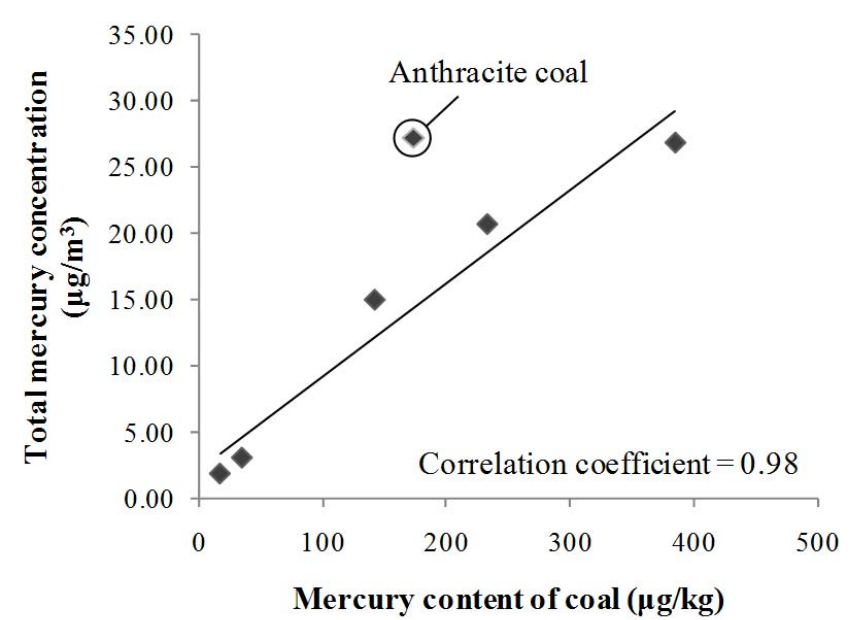

Fig. 3. Correlation between mercury content of coal and total mercury concentration in flue gas released from boilers.

than the bituminous and lignite coal-fired boilers, which is in line with a previous study in Korea (Park et al., 2008). Further study is necessary to investigate the mechanism of $\mathrm{Hg}$ release from anthracite.

During combustion, most of the $\mathrm{Hg}$ in coal is first released in $\mathrm{Hg}^{0}$ form. With the existence of $\mathrm{Cl}, \mathrm{Br}$, and particles in flue gas, part of the $\mathrm{Hg}^{0}$ is oxidized into $\mathrm{Hg}^{2+}$ either by gas phase oxidation or catalytic oxidation (Galbreath and Zygarlicke, 2000). As the flue gas temperature decreases, part of the $\mathrm{Hg}^{0}$ and $\mathrm{Hg}^{2+}$ in the gas phase condenses on or is adsorbed by fly ash particles. According to Table 3 , the speciation profile varies a lot among the tested plants. Generally the share of $\mathrm{Hg}^{0}$ to total $\mathrm{Hg}$ in flue gas released from lignite coal-burning boilers ( $80 \%$ on average) is significantly higher than that from the bituminous coal-fired boilers (30\% on average). By contrast, the share of $\mathrm{Hg}^{2+}$ to total $\mathrm{Hg}$ in flue gas released from lignite coal-burning boilers is significantly lower than that from the bituminous coal-fired boilers. The share of $\mathrm{Hg}_{p}$ to total $\mathrm{Hg}$ varies from 2 to $22 \%$, which is significantly lower than that from US tests.

Halogen in coal can be a key factor influencing $\mathrm{Hg}$ speciation. We collected data from over twenty onsite tests and analyzed the effect of chlorine content in coal on mercury speciation in the flue gas released from the boilers, as shown in Fig. 4a. We found that, with three sample points excluded, the correlation coefficient reached 0.75 , indicating that chlorine content of coal may have significant effect on distribution of different mercury species. This is in line with previous studies (Yang et al., 2007; Chen et al., 2007). The follow reactions show the mechanism of mercury changing from elemental form to oxidized form with the presence of halogens ( $\mathrm{Cl}$ and $\mathrm{Br}$ ). In the reactions, $\mathrm{M}$ stands for metal and $\mathrm{X}$ stands for halogen.

$$
\begin{aligned}
& \mathrm{MX}(\mathrm{s}) \longrightarrow \mathrm{MX}(\mathrm{g}) \\
& \mathrm{MX}(\mathrm{g}) \longrightarrow \mathrm{M}(\mathrm{g})+\mathrm{X}(\mathrm{g}) \\
& \mathrm{Hg}(\mathrm{s}) \longrightarrow \mathrm{Hg}(\mathrm{g})
\end{aligned}
$$




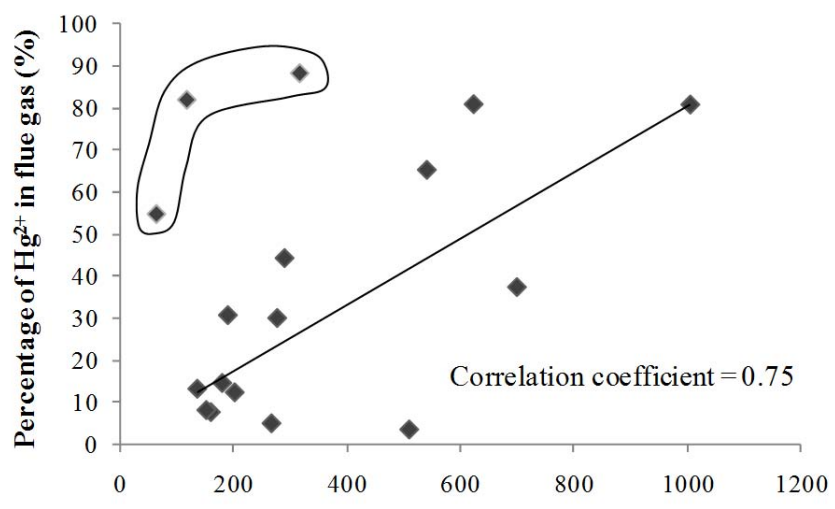

(a)

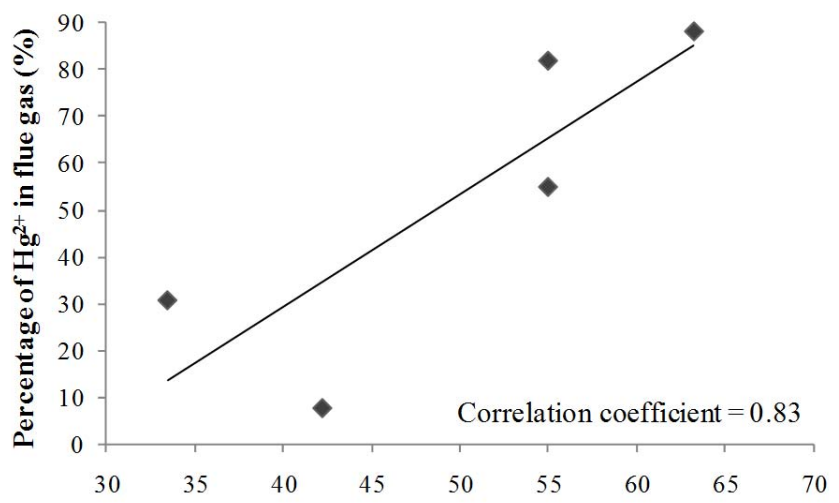

(b)

Bromine content of coal ( $\mathrm{mg} / \mathrm{kg})$

Fig. 4. Correlation between halogen content of coal and the $\mathrm{Hg}^{2+}$ percentage in flue gas released from boilers: (a) chlorine; (b) bromine.

$\mathrm{Hg}(\mathrm{g})+2 \mathrm{X}(\mathrm{g}) \longrightarrow \mathrm{HgX}_{2}(\mathrm{~g})$

The three exceptional sample points in Fig. 4a are probably because of the bromine content of coal. There is evidence that bromine species are capable of enhancing the conversion of $\mathrm{Hg}^{0}$ to $\mathrm{Hg}^{2+}$ (Liu et al., 2007; Cao et al., 2008b; Niksa et al., 2009). We found there was significant correlation between the $\mathrm{Hg}^{2+}$ percentage in flue gas released from the tested boilers and the bromine content of coal (see Fig. 4b), with a correlation coefficient of 0.83 . The bromine content of coal eventually determines the $\mathrm{Hg}^{2+}$ percentage in the flue gas more than chlorine.

The particulate concentration in flue gas is largely affected by the ash content in coal burned. Particles tend to be the adsorbents in flue gas. Mercury adsorption onto the particulates in flue gas can be considered as mono-molecule-layer adsorption. Therefore, Langmuir's adsorption isotherm formula (see Eq. 1) can be applied in this case.

$\gamma=\frac{K b p}{1+b p}$

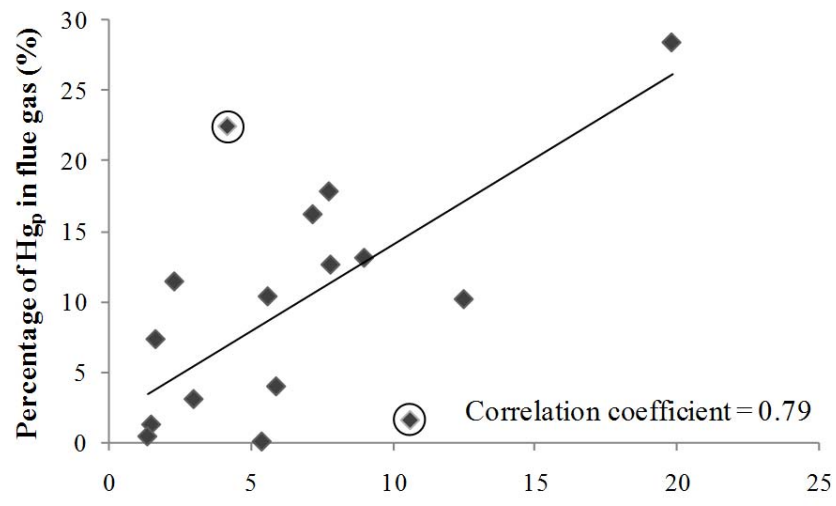

The ratio of mercury content to ash content of coal

Fig. 5. Correlation between the M/A ratio of coal and the $\mathrm{Hg}_{p}$ percentage in flue gas released from boilers.

In Eq. (1), $\gamma$ is the total amount of adsorption; $K$ and $b$ are constants; $p$ is the partial pressure of the adsorbate. Mercury is a trace element in flue gas, which means $b p \ll 1$. Accordingly, Eq. (1) can be rewritten as Eq. (2):

$\gamma=K b p$

For a certain amount of adsorbent, more mercury leads to higher mercury partial pressure, and higher partial pressure leads to larger amount of adsorption. In other words, the higher ratio of mercury content to ash content of coal (M/A ratio) contributes to higher adsorption rate, i.e. the $\mathrm{Hg}_{p}$ percentage in flue gas. The correlation between M/A ratio and $\mathrm{Hg}_{p}$ percentage was tested in Fig. 5. We found that the correlation coefficient was 0.79 when we removed two exceptional sample points. The exception might have something to do with the temperature, which is another sensitive variable in the adsorption process.

\subsubsection{Mercury behavior across APCDs}

ESP is the most commonly used APCD in coal-fired power plants. In China, more than $90 \%$ of total installed power capacity has ESPs. Particulate-bound mercury is simultaneously removed when the particles are captured by ESP. ESPs can capture nearly all $\mathrm{Hg}_{p}$, as shown in Table 3. Although gas phase mercury is barely removed by ESPs, it does transform continuously across the ducts and devices. Oxidized mercury with positive charge, on the other hand, will move forward along with the flue gas. Therefore, $\mathrm{Hg}^{2+}$ is unlikely to be adsorbed onto particles to transform to $\mathrm{Hg}_{p}$. However, some of the $\mathrm{Hg}^{0}$ will be adsorbed or oxidized into $\mathrm{Hg}_{p}$ or $\mathrm{Hg}^{2+}$ when cooling to $400^{\circ} \mathrm{C}$, which explains the fact that total gaseous mercury decreased when going through ESP in some tests (plant 1,2 and 5). The concentration of total gaseous mercury at outlet of ESP was 18-30\% lower than that at inlet of ESP for plant 1,2 and 5. Another process taking place inside ESP is the transformation of $\mathrm{Hg}^{2+}$ to $\mathrm{Hg}^{0}$. 


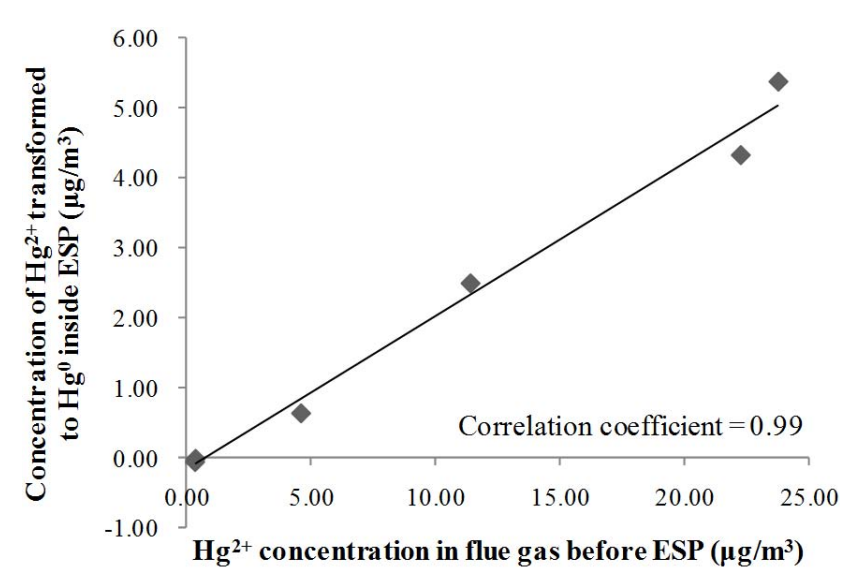

Fig. 6. Influence of $\mathrm{Hg}^{2+}$ concentration in flue gas before ESP on the transformation from $\mathrm{Hg}^{2+}$ to $\mathrm{Hg}^{0}$.

If no $\mathrm{Hg}^{2+}$ was supposed to be adsorbed to particles, then all the $\mathrm{Hg}^{2+}$ reduction occurred across the ESP because all $\mathrm{Hg}^{2+}$ was transformed into $\mathrm{Hg}^{0}$. The balance between $\mathrm{Hg}^{2+}$ and $\mathrm{Hg}^{0}$ was broken when some of the $\mathrm{Hg}^{0}$ was adsorbed onto the particles and removed by ESP. To build up a new balance, some $\mathrm{Hg}^{2+}$ converts into $\mathrm{Hg}^{\mathrm{O}}$. The rate is kinetically controlled and the concentration of $\mathrm{Hg}^{2+}$ played important role, as shown in Fig. 6. As a result, the share of $\mathrm{Hg}^{0}$ at outlet of ESP was $46 \%$ on average, which was much higher than that at outlet of ESPs tested in the United States ( $26 \%$ on average).

Wet FGD is also widely used in Chinese coal-fired power plants. Due to the solubility of $\mathrm{Hg}^{2+}$ in water, $67-98 \%$ of $\mathrm{Hg}^{2+}$ was absorbed in the scrubber solution and retained in the FGD gypsum. Higher concentration of $\mathrm{Hg}^{2+}$ in the flue gas led to higher removal efficiency in wet FGD (see Fig. 7). The reduction of $\mathrm{Hg}^{0}$ in flue gas across wet FGD was less than $30 \%$.

Plant 6 is the only tested plant installing SCR. According to Table 3, the three mercury species were redistributed across SCR. The oxidability of flue gas was enhanced in SCR due to the existence of the catalyst. The catalyst can accelerate Reaction (5):

$\mathrm{Hg}+\mathrm{O}_{2} \stackrel{\text { catalyst }}{\longrightarrow} \mathrm{Hg}^{0}$

Part of the $\mathrm{Hg}^{0}$ was thus transformed to $\mathrm{Hg}^{2+}$. The share of $\mathrm{Hg}^{2+}$ in flue gas increased from $8 \%$ before SCR to $21 \%$ after SCR. On the contrast, the share of $\mathrm{Hg}^{0}$ in flue gas decreased from $81 \%$ before SCR to $54 \%$ after SCR. Ammonia injection before SCR might have positive effect on the adsorption of mercury onto the particulate matter. That could be the reason why the $\mathrm{Hg}_{p}$ concentration increased. More tests are needed to confirm the effects of SCR and its catalysts on mercury speciation.

Plant 5 is the only plant with CFB-FGD plus FF system. The sticky $\mathrm{Hg}^{2+}$ in flue gas tends to adsorb on the particles

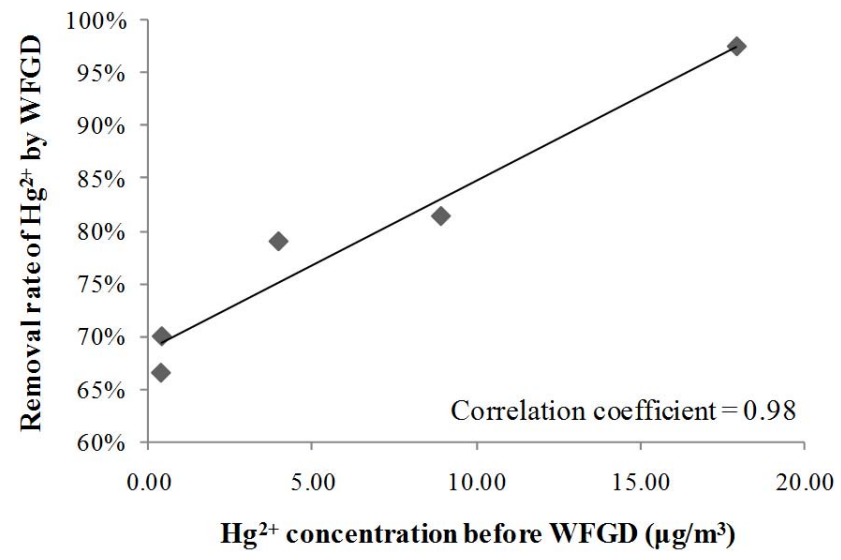

Fig. 7. Influence of $\mathrm{Hg}^{2+}$ concentration before wet FGD on the removal rate of $\mathrm{Hg}^{2+}$ by wet FGD.

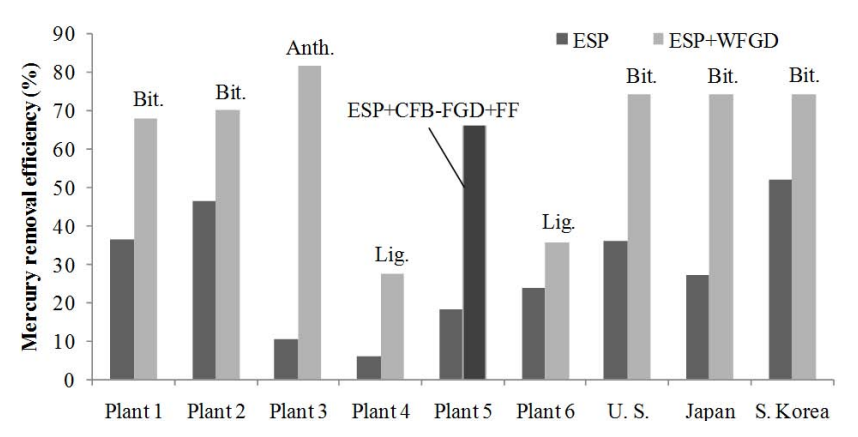

Fig. 8. Comparison of mercury removal efficiencies.

when flue gas goes through CFB-FGD and then be captured by FF system. Due to the high percentage of $\mathrm{Hg}^{2+}$ in flue gas after ESP, the removal efficiency of CFB-FGD+FF for $\mathrm{Hg}^{2+}$ is over $80 \%$.

Final emission from stack to the atmosphere varied from 1.22 to $9.60 \mu \mathrm{g} / \mathrm{m}^{3}$, and was dominated by $\mathrm{Hg}^{0}$. For the boilers with wet FGD systems, the share of $\mathrm{Hg}^{0}$ to total $\mathrm{Hg}$ in stack gas to the atmosphere was $75-94 \%$. For the boiler with ESP+CFB-FGD+FF system, the share of $\mathrm{Hg}^{0}$ to total $\mathrm{Hg}$ in stack gas to the atmosphere was $67 \%$.

\subsection{Mercury removal efficiencies of APCDs}

In this study, the average mercury removal efficiencies of the ESP, ESP+WFGD, and ESP+CFB-FGD+FF systems were $24 \%, 73 \%$ and $66 \%$, respectively, as shown in Fig. 8. The removal efficiencies of ESP for tested power plants, including the results from US, Japan and South Korea, varied significantly from 6 to $52 \%$. The mercury removal efficiencies of ESP+WFGD were around 70\% for bituminous coal-fired power plants. The Hg removal efficiency for anthracite coalburning unit is higher than that for bituminous coal. The lignite coal-burning plants have lowest $\mathrm{Hg}$ removal efficiencies. 
Table 4. Mercury contents in solid samples.

\begin{tabular}{lllllll}
\hline & Plant 1 & Plant 2 & Plant 3 & Plant 4 & Plant 5 & Plant 6 \\
\hline Feed coal $(\mu \mathrm{g} / \mathrm{kg})$ & $233 \pm 12(6)$ & $142 \pm 38(3)$ & $174 \pm 19(6)$ & $35 \pm 10(5)$ & $385 \pm 113(5)$ & $17 \pm 5(7)$ \\
Bottom ash $(\mu \mathrm{g} / \mathrm{kg})$ & $3 \pm 1(6)$ & $16 \pm 4(4)$ & $7 \pm 3(3)$ & $3 \pm 1(3)$ & $3 \pm 1(6)$ & $1 \pm 0(7)$ \\
Fly ash $(\mu \mathrm{g} / \mathrm{kg})$ & $295 \pm 59(5)$ & $245 \pm 34(5)$ & $160 \pm 19(4)$ & $10 \pm 2(6)$ & $134 \pm 36(4)$ & $24 \pm 3(6)$ \\
Gypsum $(\mu \mathrm{g} / \mathrm{kg})$ & $368 \pm 108(3)$ & $561 \pm 8(3)$ & $309 \pm 12(6)$ & $90 \pm 7(4)$ & & $38 \pm 4(5)$ \\
Fine ash $(\mu \mathrm{g} / \mathrm{kg})$ & & & & & $2945 \pm 132(3)$ & \\
\hline
\end{tabular}

Note: the numbers in brackets are number of samples analyzed.

Table 5. Mass balance and emission factors of the tested coal-fired power plants.

\begin{tabular}{lllllll}
\hline & Plant 1 & Plant 2 & Plant 3 & Plant 4 & Plant 5 & Plant 6 \\
\hline Hg in (g/d) & 570.7 & 757.6 & 479.6 & 138.6 & 799.2 & 26.4 \\
Feed coal & 570.7 & 757.6 & 479.6 & 138.6 & 799.2 & 26.4 \\
Hg out (g/d) & 554.3 & 773.4 & 556.7 & 120.0 & 816.8 & 27.5 \\
Bottom ash & 0.2 & 7.3 & 0.1 & 0.1 & 0.2 & 0.0 \\
Fly ash & 194.9 & 332.5 & 101.0 & 5.4 & 88.6 & 6.5 \\
Gypsum & 200.9 & 237.1 & 351.8 & 27.5 & & 3.5 \\
Fine ash & & & & & 464.3 & \\
Stack gas & 158.3 & 196.5 & 103.7 & 87.0 & 263.7 & 17.5 \\
Hg out/in $(\%)$ & 97.1 & 102.1 & 116.1 & 86.5 & 102.2 & 104.3 \\
Emission factor $(\mathrm{mg} \mathrm{Hg/t} \mathrm{coal)}$ & 75 & 43 & 32 & 25 & 131 & 11 \\
\hline
\end{tabular}

The overall mercury removal efficiency was in a logarithmic correlation with the total mercury concentration in the flue gas after the boiler (Fig. 9). Shape of the correlation curve was determined by the chlorine content, bromine content, and M/A ratio of the coal. The combination of $\mathrm{SCR}+\mathrm{ESP}+\mathrm{WFGD}$ has relatively higher mercury removal efficiency than ESP+WFGD due to the oxidizing effect of SCR. Combination of ESP+CFB-FGD+FF has a relatively lower efficiency than ESP+WFGD, which indicates stronger co-benefit of mercury abatement from wet FGD than from dry FGD system.

\subsection{Mercury mass balance in coal-fired power plants}

Table 4 shows the Hg concentrations of solid and liquid samples collected in the field. The Hg concentration in bottom ash ranged from 1 to $16 \mu \mathrm{g} / \mathrm{kg}$. The concentration of $\mathrm{Hg}$ in fly ash from the ESP hopper varied from 10 to $295 \mu \mathrm{g} / \mathrm{kg}$. The $\mathrm{Hg}$ content of gypsum (by-product from wet FGD) ranged from 38 to $561 \mu \mathrm{g} / \mathrm{kg}$. In addition, the $\mathrm{Hg}$ in fine ash from FF was $2945 \mu \mathrm{g} / \mathrm{kg}$. All of the collected data have been used for the calculation of mercury mass balance in the coal-fired power plants.

The mercury balance was estimated based on the results of $\mathrm{Hg}$ analysis in above sessions. Table 5 gives the details of the daily average mass balance calculations for all the six plants. For all the six power plants, the mercury balances recovery rates ranged from 87 to $116 \%$ of the mercury in

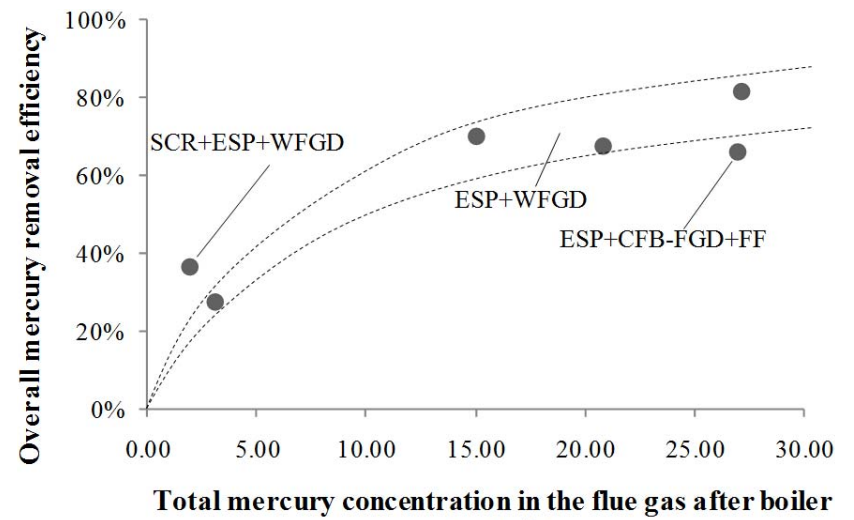

$\left(\mu \mathrm{g} / \mathrm{m}^{3}\right)$

Fig. 9. Overall mercury removal efficiencies of tested power plants.

feed-coals. All the results were within the acceptable error range of $\pm 20 \%$.

The mass balance results indicate the fate of mercury across APCDs in power plants. Figure 10 is the summarized diagram with mass distribution of mercury in the coal-fired power plants. Only a very small part $(<1 \%)$ of $\mathrm{Hg}$ in coal was retained in bottom ash. About 5-43\% of $\mathrm{Hg}$ is collected in the ESP fly ash hopper. About $13-63 \%$ of the $\mathrm{Hg}$ in coal is captured in gypsum of wet FGD and $19-72 \%$ of $\mathrm{Hg}$ is emitted to the atmosphere. 


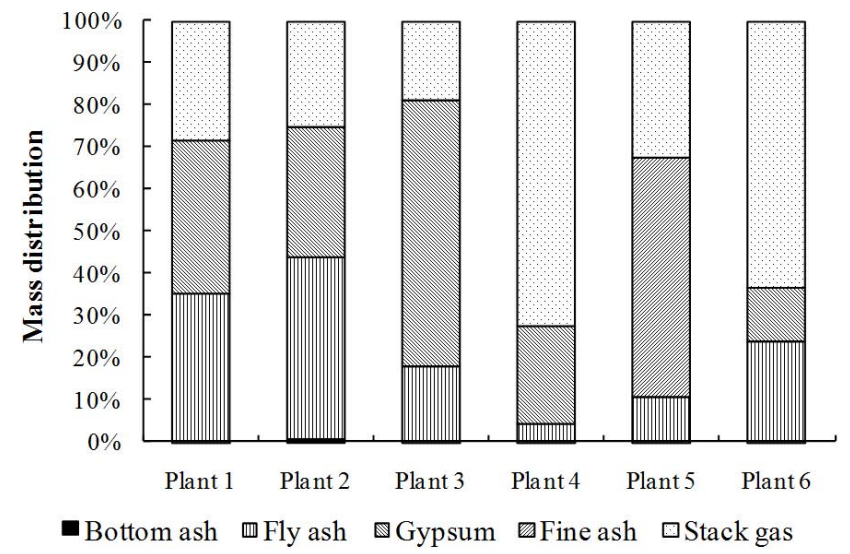

Fig. 10. Mass distribution of mercury in the coal-fired power plants.

\subsection{Mercury emission factors}

The atmospheric mercury emission factors of each tested power plants are given in Table 5. The emission factor for ESP+WFGD was in the range of 25 to $75 \mathrm{mg} \mathrm{Hg} / \mathrm{t}$ coal. That for SCR+ESP+WFGD was $11 \mathrm{mg} \mathrm{Hg} / \mathrm{t}$ coal and for $\mathrm{ESP}+\mathrm{CFB}-\mathrm{FGD}+\mathrm{FF} 131 \mathrm{mg} \mathrm{Hg} / \mathrm{t}$ coal. The wide distribution of the emission factors obtained in this study indicates that mercury emissions in Chinese power plants are rather complicated. Therefore, great caution shall be taken when apply the mercury emission characteristics measured in US or other countries to estimate mercury emissions in China.

\section{Conclusions}

To investigate the $\mathrm{Hg}$ emission characteristics from coal-fired power plants in China, $\mathrm{Hg}$ sampling was carried out at six typical power plants burning various types of coals. It was found that the $\mathrm{Hg}$ emission was dependent on coal properties and APCDs configuration.

Type of coal was a major factor affecting the $\mathrm{Hg}$ emission and speciation in flue gas right after the coal-fired boilers without controls. Anthracite coal with a higher concentration of $\mathrm{Hg}$ emitted than bituminous coal. Mercury speciation was mainly influenced by the content of chlorine and bromine in coal.

Mercury concentration and speciation was changed across APCDs. Some of the $\mathrm{Hg}^{0}$ in flue gas was oxidized to $\mathrm{Hg}^{2+}$ in SCR. Large amounts of particulate-bound $\mathrm{Hg}$ were removed through ESP and small amounts of $\mathrm{Hg}^{0}$ oxidized to $\mathrm{Hg}^{2+}$. Around $67-98 \%$ of $\mathrm{Hg}^{2+}$ in flue gas was absorbed in the scrubber solution and retained in the FGD gypsum. CFBFGD plus FF system also removed $80 \%$ of $\mathrm{Hg}^{2+}$.

For the six power plants tested, the mercury mass balances varied from 87 to $116 \%$ of the input coal mercury to the plants, which was enough to describe the distribution of mercury in the plant. The distribution of mercury con- firmed significant amount of Hg removal by ESP and FGD systems. The average mercury removal efficiencies of the ESP, ESP+WFGD, and ESP+CFB-FGD+FF systems were $24 \%, 73 \%$ and $66 \%$, respectively. And $19-72 \%$ of $\mathrm{Hg}$ in flue gas was emitted to the atmosphere through stack, which was dominated by $\mathrm{Hg}^{0}$.

For a better reliable understanding of the mercury behavior from a coal-fired power plant and other combustion facilities, long-term experiment plan and continuously monitoring of the flue gas are necessary.

Acknowledgements. This work was sponsored by Natural Science Foundation of China (No. 20937002 ), Government of Norway (Sino-Norwegian cooperation Project "Capacity building for reducing mercury pollution in China-Case Study in Guizhou province"), and Ministry for the Environment, Land and Sea, Republic of Italy. Additional support was from State Key Joint Laboratory of Environment Simulation and Pollution Control in China (No. 08Z03ESPCT).

Edited by: R. Ebinghaus

\section{References}

ASTM D6784-02: Standard test method for elemental, oxidized, particle-bound, and total mercury in flue gas generated from coal-fired stationary sources (Ontario-Hydro Method), ASTM International, Pennsylvania, USA, 2002.

Cao, Y., Cheng, C., Chen, C., Liu, M., Wang, C., and Pan, W.: Abatement of mercury emissions in the coal combustion process equipped with a Fabric Filter Baghouse, Fuel, 87, 3322-3330, 2008a.

Cao, Y., Gao, Z., Zhu, J., Wang, Q., Huang, Y., and Chiu, C.: Impacts of halogen additions on mercury oxidation, in a slipstream selective catalyst reduction (SCR), reactor when burning subbituminous coal, Environ. Sci. Technol., 42(1), 256-261, $2008 \mathrm{~b}$.

Chen, L., Duan, Y., Zhuo, Y., Yang, L., Zhang, L., Yang, X., Yao, Q., Jiang, Y., and Xu, X.: Mercury transformation across particulate control devices in six power plants of China: The co-effect of chlorine and ash composition, Fuel, 86(4), 603-610, 2007.

Clack, H.: Mercury capture within coal-fired power plant electrostatic precipitators: model evaluation, Environ. Sci. Technol., 43, 1460-1466, 2009.

Galbreath, K. C. and Zygarlicke, C. J.: Mercury transformations in coal combustion flue gas, Fuel Process. Technol., 65-66, 289310, 2000.

Ito, S., Yokoyama, T., and Asakura, K.: Emissions of mercury and other trace elements from coal-fired power plants in Japan, Sci. Total Environ., 368, 397-402, 2006.

Lee, C. W., Serre, S. D., Zhao, Y., Lee, S. J., and Hastings, T. W.: Mercury oxidation promoted by a selective catalytic reduction catalyst under simulated powder river basin coal combustion conditions, J. Air Waste Manage., 58, 484-493, 2008.

Lee, S. J., Seo, Y. C., Jang, H. N., Park, K. S., Baek, J. I., An, H. S., and Song, K. C.: Speciation and mass distribution of mercury in a bituminous coal-fired power plant, Atmos. Environ., 40, 2215 2224, 2006. 
Liu, S., Yan, N., Liu, Z., and Qu, Z.: Using bromine gas to enhance mercury removal from flue gas of coal-fired power plants, Environ. Sci. Technol., 41(4), 1405-1412, 2007.

Meij, R., Vredendregt, L. H. J., and Winkel, H.: The fate and behavior of mercury in coal-fired power plants, J. Air Waste Manage., 52, 912-917, 2002.

Meij, R. and Winkel, H.: Mercury emissions from coal-fired power stations: The current state of the art in the Netherlands, Sci. Total Environ., 368(1), 393-396, 2006.

Niksa S, and Fujiwara $\mathrm{N}$ : Predicting complete $\mathrm{Hg}$ speciation along coal-fired utility exhaust systems, in: EPRI-DOE-EPAA\&WMA combined utility air pollution control symposium: the MEGA symposium, paper no. 45. Washington DC, USA, 2004.

Pacyna, E. G., Pacyna, J. M., Steenhuisen, F., and Wilson, S.: Global anthropogenic mercury emission inventory for 2000, Atmos. Environ., 40(22), 4048-4063, 2006.

Park, K. S., Seo, Y. C., Lee, S. J., and Lee, J.: Emission and speciation of mercury from various combustion sources, Powder Technol., 180, 151-156, 2008.

Pavlish, J. H., Sondreal, E. A., Mann, M. D., Olson, E. S., Galbreath, K. C., Laudal, D. L., and Benson, S. A.: Status review of mercury control options for coal-fired power plants, Fuel Process. Technol., 82(2-3), 89-165, 2003.

Pirrone, N., Cinnirella, S., Feng, X., Finkelman, R. B., Friedli, H. R., Leaner, J., Mason, R., Mukherjee, A. B., Stracher, G., Streets, D. G., and Telmer, K.: Global Mercury Emissions to the Atmosphere from Natural and Anthropogenic Sources, in: Mercury Fate and Transport in the Global Atmosphere: Emissions, Measurements and Models, edited by: Mason, R. and Pirrone, N., Springer USA, 1-47, doi:10.1007/978-0-387-93958-2, 2009.

Ren, D., Zhao, F., Dai, S., Zhang, J., and Luo, K.: Geochemistry of Trace Elements in Coal, (in Chinese), Science Press, Beijing, China, 2006.

Srivastava, R. K., Hutson N., Martin B., Princiotta F., and Staudt, J.: Control of mercury emissions from coal-fired electric utility boilers: an overview of the status of mercury control technologies, Environ. Sci. Technol., 40(5), 1385-1393, doi:10.1021/es062639u, 2006.

Streets, D. G., Hao, J., Wu, Y., Jiang, J., Chan, M., Tian, H., and Feng, X.: Anthropogenic mercury emissions in China, Atmos. Environ., 40(39), 7789-7806, 2005.

Streets, D. G., Zhang, Q., and Wu, Y.: Projections of global mercury emissions in 2050, Environ. Sci. Technol., 43(8), 2983-2988, 2009.
Tang, S., Feng, X., Qiu, J., Yin, G., and Yang, Z.: Mercury speciation and emissions from coal combustion in Guiyang, Southwest China, Environ. Res., 105(2), 175-182, 2007.

US EPA: Mercury study report to congress, vol. VIII, EPA-452/R97-010, US Environmental Protection Agency, Washington, DC, USA, 1997.

US EPA: Control of mercury emissions from coal-fired electric utility boilers, EPA-600/R-01-109, US Environmental Protection Agency, Washington, DC, USA, 2002a.

US Environmental Protection Agency: ICR data, online available at: http://www.epa.gov/ttn/atw/combust/utiltox/icrdata.xls, 2002 b.

US Geological Survey (USGS): Mercury content in coal mines in China, unpublished data, 2004.

Wu, Y., Wang, S., Streets, D. G., Hao, J., Chan, M., and Jiang, J.: Trends in anthropogenic mercury emissions in china from 1995 to 2003, Environ. Sci. Technol., 40(17), 5312-5318, 2006.

Wu, Y., Streets, D. G., Wang, S., and Hao, J.: Uncertainties in estimating mercury emissions from coal-fired power plants in China, Atmos. Chem. Phys. Discuss., 9, 23565-23588, 2009, http://www.atmos-chem-phys-discuss.net/9/23565/2009/.

Yang, X., Duan, Y., Jiang, Y., and Yang, L.: Research on mercury form distribution in flue gas and fly ash of coal-fired boiler, (in Chinese with abstract in English), Coal Sci. Technol., 35(12), 55-58, 2007.

Yokoyama, T., Kazuo, U., Matsuda, A. H., Ito, S., and Noda, N.: Mercury emissions from a coal-fired power plant in Japan, Sci. Total Environ., 259, 97-103, 2000.

Zhang, L., Zhuo, Y., Chen, L., Xu, X., and Chen, C.: Mercury emissions from six coal-fired power plants in China, Fuel Process. Technol., 89(11), 1033-1040, 2008.

Zhao, Y., Wang, S., Duan, L., Lei, Y., Cao, P., and Hao, J.: Primary air pollutant emissions of coal-fired power plants in China: current status and future prediction, Atmos. Environ., 42(36), 84428452, 2008.

Zheng, L., Liu, G., Qi, C., Chen, Y., and Zhang, Y.: Study on environmental geochemistry of mercury in Chinese coals, J. Univ. Sci. Technol. B., 37(8), 953-963, 2007a.

Zheng, L., Liu, G., and Zhou, C.: The distribution, occurrence and environmental effect of mercury in Chinese coals, Sci. Total Environ., 384, 374-383, 2007b. 